\title{
Two Documents from Cairo Museum ${ }^{(*)}$
}

\section{1- List of Names}

\section{(P. Cairo Museum SR 3049/95 Verso)}

A dark brown papyrus damaged in the right upper side. It measures $10 \mathrm{~cm}$ width and 18. $2 \mathrm{~cm}$ height, mutilated and suffers from some holes. The upper, lower and left margins are kept. The document contains eighteen lines, the ink in the beginning of the first line and the end of the fifth line is so abraded that makes the reading difficult. The letters have been written separately across the fibers on the verso side in a professional semi cursive hand.

This text is one of a papyrus collection found in Fayum province by the farmers and brought to the Egyptian Museum in Cairo in 26 June 1927. The majority of these papyri are from Theadelphia village (Harit) and a very few from Karanis village (Kom Oshim).

This text is a list of sixteen men, most probably of persons available for service. One of those men, Heron son of Aphrodisios (line 6), has been mentioned in Soterichos archive, who lived in Theadelphia in the second half of the $1^{\text {st }}$ and the beginning of the $2^{\text {nd }}$ century $^{(1)}$. He was a lessor of a palm-grove together with another person, and gave the lessee Soterichos a receipt for rent ${ }^{(2)}$. Heron the son of Aphrdisios was in the year 88 $\mathrm{AD}$ about forty years old ${ }^{(3)}$, therefore one may assume that this list returns to the same place and date of Soterichos archive.

The names Heras (line 9) and Tesenouphis (line 11) are names for men or women ${ }^{(4)}$ (see note lines 9, 11). All the other fourteen names of the list are Masculine, therefore these names should be for men and not for women. The craft of Tenesouphis, as a

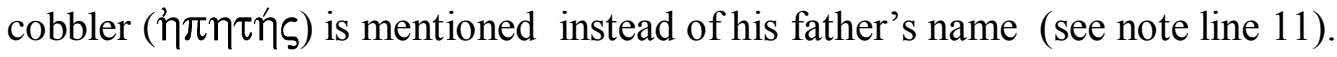

The name Sambas in line 13 is mentioned as son Tapsois, which is a feminine name ${ }^{(5)}$. Sambas was fatherless ( $\left.\dot{\alpha} \pi \alpha \dot{\alpha} \omega \rho\right)$ and this name is his mother's name. More than 800 attestations of fatherlessness are known in papyri, from the beginning of the first to the late third century. Many of the apatores were children of roman soldiers, but not all, since the term is attested a few times after 197 AD, when the ban on the roman soldiers' marriage is lifted. The term $\alpha \pi \alpha$ $\tau \omega \rho$ is attested in Arsinoite and many other nomes, while $\chi \rho \eta \mu \alpha \tau i \zeta \omega \nu \mu \eta \tau \rho \delta_{s}$ "officially described as the son of (name of mother)" was found in Oxyrhynchite nome ${ }^{(6)}$. The term $\alpha \pi \alpha \dot{\alpha} \omega \rho$ is usually noted

(*) The first document has been edited in Festschrift in Honor of Prof. Abdel Mooti Shaarawi, Classical Papers vol. IX, Cairo University 2009, pp.77ff., but p.79 is not printed in this edition. The second document has been edited in Festschrift in Honor of Prof. M. Hamdi Ibrahim, Selselat Alrwad, Book 2, Cairo University 2011, pp.1ff.

(1) Sayed Omar, Das Archiv des Soterichos, Westdeutscher Verlag, Opladen Germany 1979.

(2) P.Soter. 6 (4. November 88 AD), Theadelphia.

(3) Ibid line 7.

(4) See Preisigke, Namenbuch s. v.; Foraboschi, Onomasticon, s.v.

(5) See ibid.

(6) See Myrto Malouta, The Terminology of Fatherlessness in Roman Egypt, Proceedings of the 24th International Congress of Papyrology, Helsinki Finland 2007, Vol.II pp.615ff. 
before the mother's name, but in some cases, as here, the term is not mentioned (see note line 13).

\section{Text:}

$\tau$ (o) $\alpha \underline{u} \tau(\mathrm{o}) \tau \alpha \beta \lambda \underline{\hat{l}}(\mathrm{ov})$

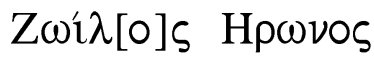

I $\alpha \sigma \omega \nu$ X $\alpha i p \eta ́ p o v o s$

$4 \mathrm{~K} \alpha \imath \pi i \omega[v]$ Epuíov

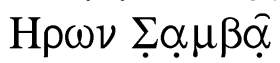

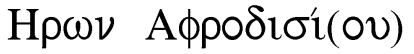

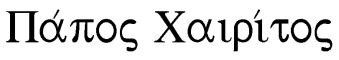

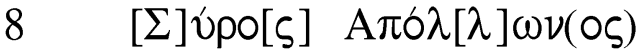

$\mathrm{H} \rho \hat{\alpha} \varsigma \mathrm{X} \rho v \sigma \alpha \phi[10] v$

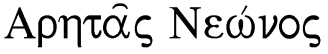

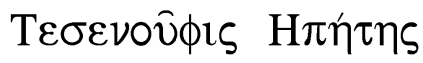

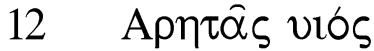

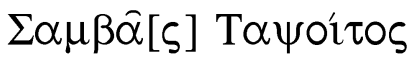

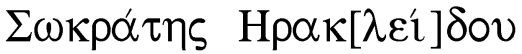

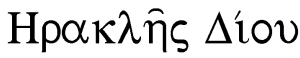

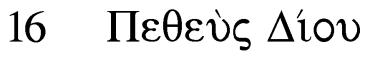

$M v \sigma \theta \alpha \rho[\hat{\alpha} \varsigma] \Pi \tau \circ \lambda \varepsilon \mu \alpha[10] v$

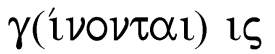

\section{Translation:}

The same list

Zoilos, son of Heron

Iason, son of Chairemon

Kaipion, son of Hermias

Heron, son of Sambas

Heron, son of Aphrodisios

Papos, son of Chairis

Syros, son of Apollon

Heras, son of Chrysaphios

Aretas, son of Neon

Tesenouphis, son of Epetes (the cobbler)

Aretas, his son

Sambas, son of Tapsois

Sokrates, son of Heraklides

Herakles, son of Dios

Petheus, son of Dios

Mystharas, son of Ptolemaios

(The total) 16 


\section{Commentary:}

$1 \tau \alpha \beta \lambda !(O v)$ the reading is doubtful. The letters $\lambda l$ are written together as one letter and could be $v$, therefore one may read $\tau \alpha \beta(\lambda i o) v$

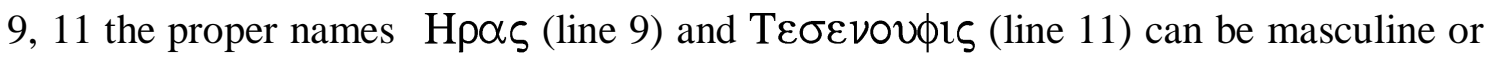
feminine, see introduction. This kind of Greek names is very rare. The following proper names are also from the same kind:

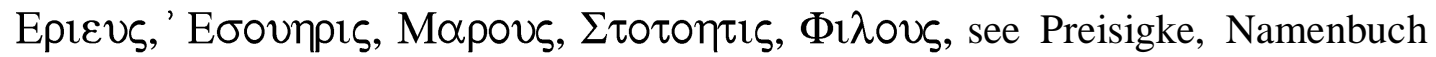
s. v.; Foraboschi, Onomasticon, s. v.

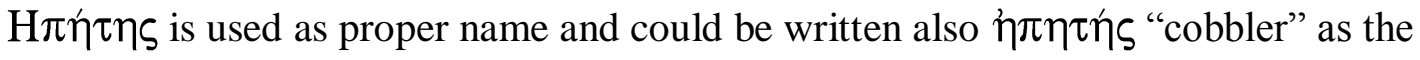
craft of Tesenouphis, cf. P.Tebt.III 1076, 22 (List of names, late second century BC).

13 Tayors is a woman's name, see the introduction. The mother's name of the

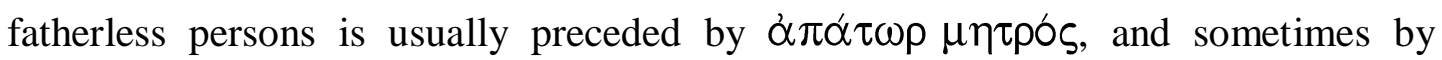
$\dot{\alpha} \pi \alpha \dot{\tau} \tau \omega \rho$, or $\mu \eta \tau \rho \varsigma_{\varsigma}$ only. In rare conditions it is mentioned directly without any term before the mother's name, as here, cf. P. Amh. II 98, 6 = C. Pap. Jud. III 468, 6 (Abstract of contracts from Hermopolis, after 28. October 211? AD):

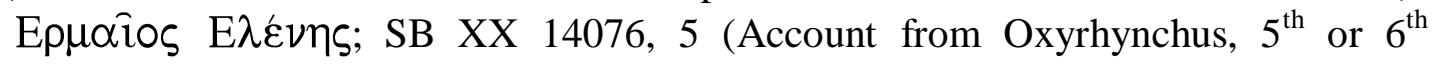
century $\mathrm{AD}): \delta(1 \dot{\alpha}) \Pi \alpha \mu \circ v \theta i o v$ E $\lambda \dot{\varepsilon} \nu \eta s$. There is also another way to write the mother's name of the fatherless persons as in P. Athen. 43, 3 Verso (Arsinoite,

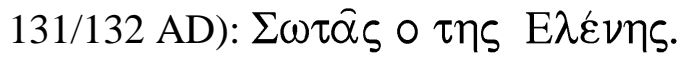

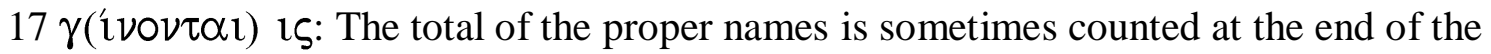
list. This list contains of sixteen men. 


\section{Two Documents from Cairo Museum}

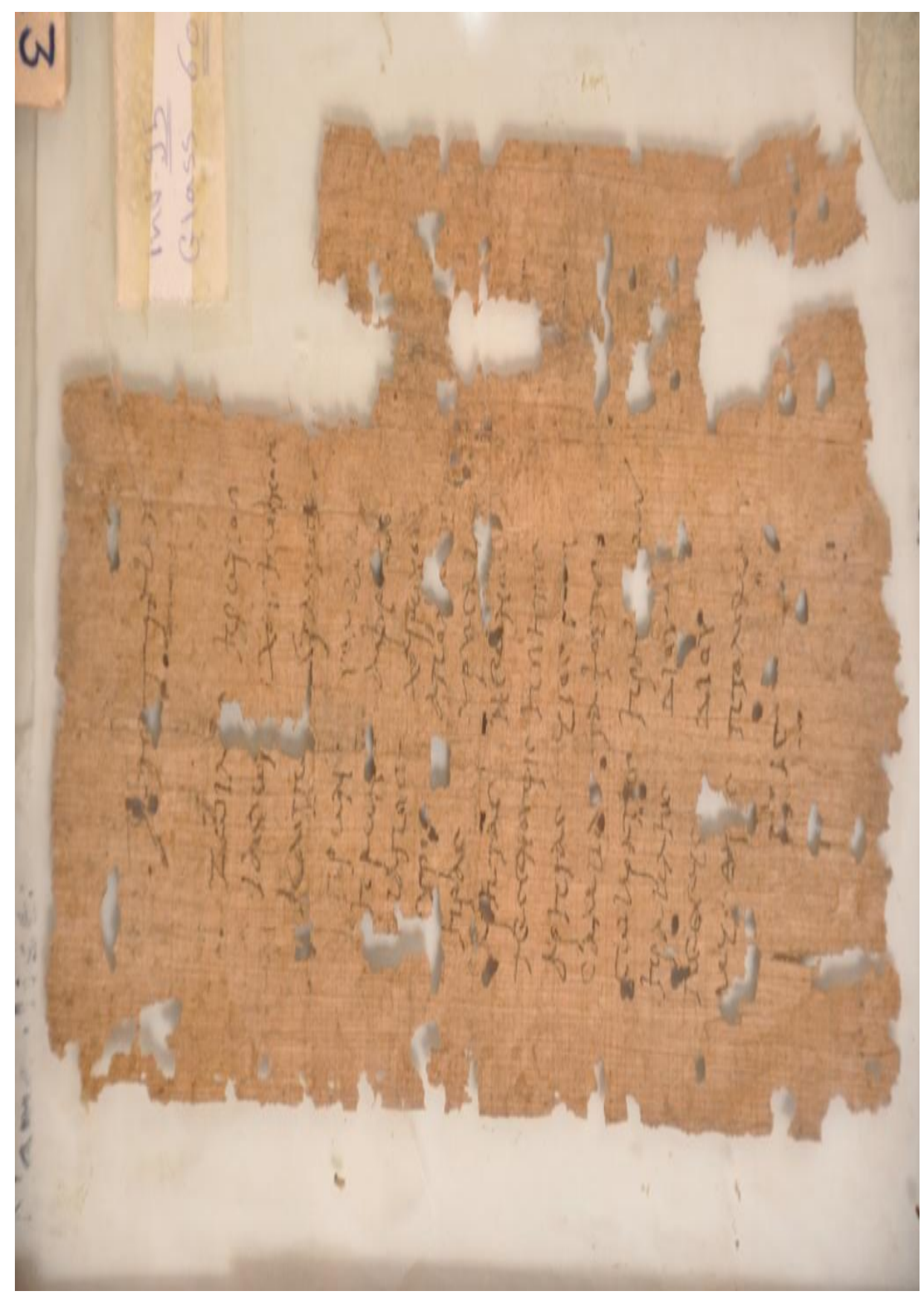




\section{2- Census Declaration from Theadelphia}

\section{(P. Cairo Museum SR 3049/77)}

This text is one of a papyrus-collection found in Fayum by the farmers and brought to the Cairo Museum in 26 June 1927. It is registered in the Special Register under number SR 3049. Six census declarations from this collection have been published in $1985^{(7)}$. One of these declarations (SR 3049/73) is a copy of P. Berliner Leihgabe I 16 C (= col. III), which is a part of a $\tau o ́ \mu \circ \varsigma \sigma v \gamma \kappa o \lambda \lambda \eta \sigma u \mu \circ \varsigma$, while another two declarations (SR 3049/72 and 74) are copies of BGU XI 2089. The texts of Cairo Museum were more complete and so it helped the publisher to correct and complete the lacunae of the BGU text ${ }^{(8)}$.

The present papyrus is also another census declaration, which is a new copy of $\mathrm{P}$. Berliner Leihgabe I 16 B (=col. II), a part of the aforementioned $\tau$ ó $\mu \circ$ $\sigma \mho \gamma \kappa о \lambda \lambda \eta \sigma \mu \rho \varsigma$. This time the Berliner copy is more complete than the Cairo Museum text, so it helped to complete the lacunae.

In roman Egypt the declarant was obliged to submit copies of his declaration to various officials concerned with the census: the $\sigma \tau \rho \alpha \tau \eta \gamma \delta \zeta$, the $\beta \alpha \sigma \imath \lambda \imath$ ios

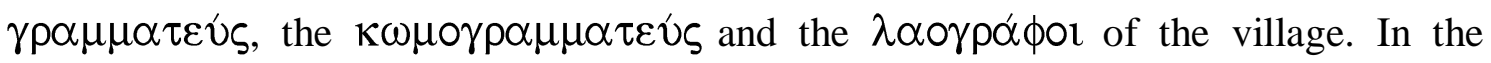
capital cities of the nomes, the declarations were addressed either to the two

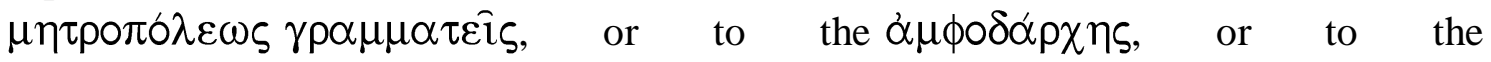
$\dot{\alpha} \mu \phi о \delta о \gamma \rho \alpha \mu \mu \alpha \tau \varepsilon \hat{\zeta} \zeta$. The declarant had to keep also for himself one or more copies for each of the bureau, and was obliged to purchase from five to ten sheets of papyrus for these reports ${ }^{(9)}$. Six copies of the same declaration from Soknopaiou Nesos village are survived, all in the same hand and identical except for the address. Two copies are addressed to the strategos of Arsinoite nome, Heraklides division (BGU I 224; II 410), one to the basilikos grammateus (P. Grenf. II 55), two to the komogrammateus (BGU I 90; II 537), and one to the laographoi of that village (BGU I 225). For this reason we find more than one copy of the same declaration addressed to the same official.

Both P. Berl. Leihg. I 16C and P.Cairo Museum SR 3049/73 are two identical copies, while P. Berl. Leihg. I 16B and the present text are another two identical copies, addressed to the same strategos. The existence of one copy in Berlin Museum and the other in the Egyptian Museum in Cairo is not common.

The Prefect of Egypt Gaius Vibius Maximus declared in the year 104 AD the census edict as follows: the census by household having begun, it is essential that all those who

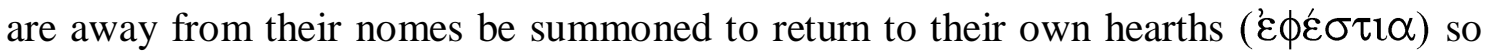
that they may perform the customary business of registration ${ }^{(10)}$.

(7) Sayed Omar, Sechs Zensus-Eingaben aus Theadelphia (P. Cairo Museum SR 3049/ 69-74), Bulletin of the Center of Papyrological Studies, Ain Shams University (PACPS), Cairo (1985), Vol. I, pp. 37 50 .

(8) Ibid. p. 50.

(9) Wallace, Taxation in Egypt, New York (1969), pp. 99f.

(10) P. London III 904.20-26:

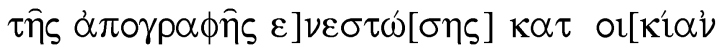


Panephremmis, the son of Heron, grandson of Heron, whose ' $\dot{\phi} \phi \dot{\varepsilon} \sigma \tau 10 v$ was Theadelphia village, declares himself for the census of the $23^{\text {rd }}$ year of the Imperator Antoninus Pius (A D 159/160), that his present residence is in a tenement-house of an estate in the village Apias of Themistes division (see note line 11). The exact location of Apias village is unknown, but it was probably close to the lake Moeris and not too far from Euhemeria ( see note line 12 ). Panephremmis declares his residence only and does not give any details of his property or household.

The declaration is filed in Mesore, the last month of the first year of the Imperators Marcus Aurelius and Lucius Verus (25 July-23 August 161), about one year after the official date of the census, like the most Arsinoite declarations after the first century ${ }^{(11)}$.

The census in Egypt was taken at intervals of fourteen years. We know more than three hundred census declarations filed by Egyptian declarants in the roman period from $\mathrm{AD} 11 / 12$ to $257 / 258$, which enriched our knowledge about the demography of roman Egypt. Most of these declarations are from the second and third centuries. About $75 \%$ of the documents come from Arsinoite and Oxyrhynchite nomes ${ }^{(12)}$. There are no published extant declarations later than $\mathrm{AD} 258$. It might be merely one of the accidents of survival, or it is possible that a change was introduced by the Imperator Aurelianus in AD 272, when the first census after AD 258 would normally has occurred ${ }^{(13)}$.

The papyrus measures $8 \mathrm{~cm}$ width, $23.7 \mathrm{~cm}$ height, dark-brown colored, damaged in the upper part and the right side. It is mutilated and suffers from some holes. The upper, left and lower margins are kept. The ink in some letters is so abraded that make the reading difficult. The document has been written along the fibers on the recto side in a professional cursive hand. The Verso is blank.

Text :

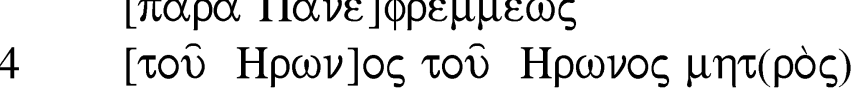

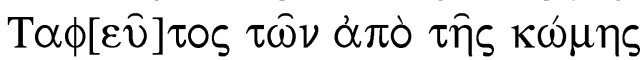

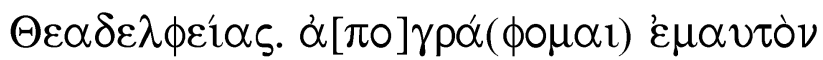

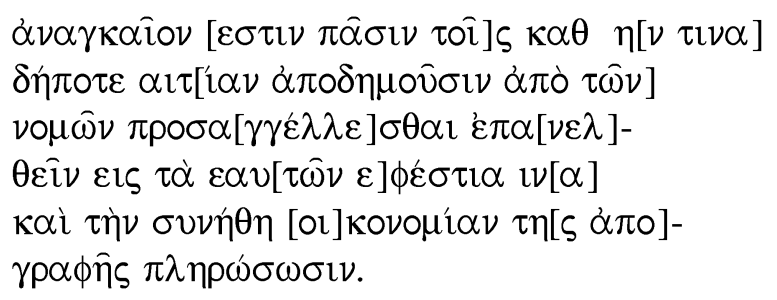

(11) Hombert M. - Preaux C., Recherches sur le recensment dans l'Egypte romaine (P. Bruxelles inv. E. 7616), Leiden (1952), pp. 77-84.

(12) Bagnall R. - Frier B.W., The Demography of Roman Egypt, Cambridge University Press (1994), introduction p. xv.

(13) Wallace, Taxation p. 98. 


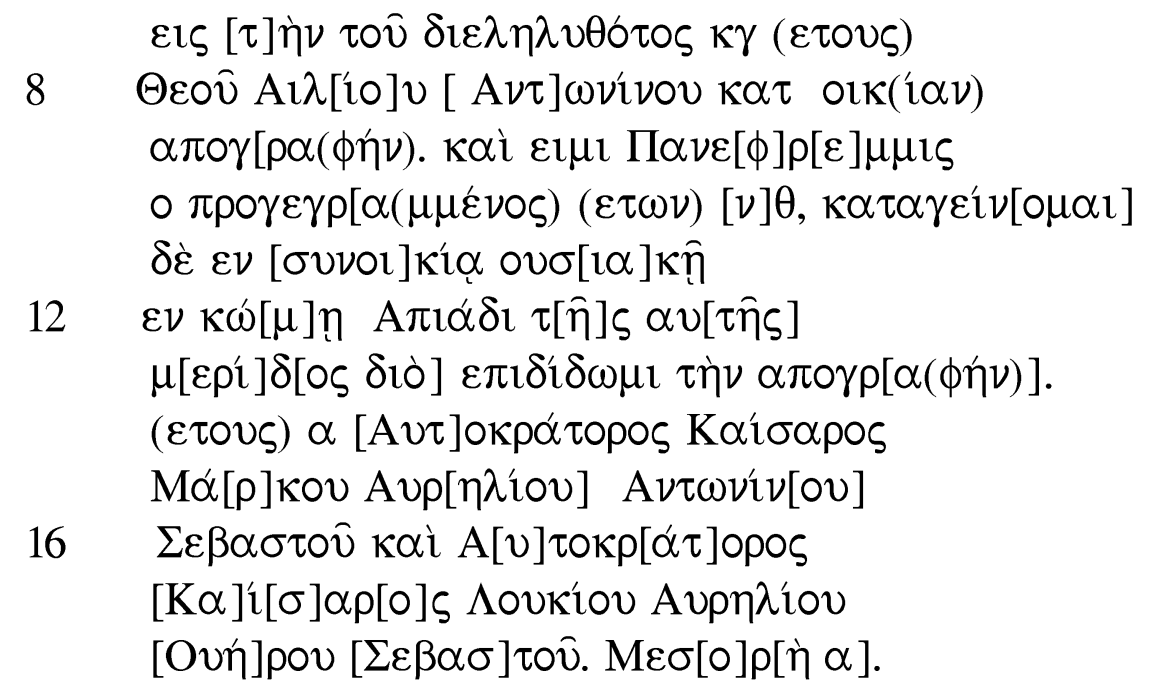

6. $\alpha \pi \circ \gamma \rho$ ' pap.

7. $\kappa \gamma L$ pap.

8. $\mathrm{Ol}^{\mathrm{K}}$ pap.

10. $L[v] \theta$ pap.

14. $L \alpha$ pap.

\section{Translation:}

To Harpocration, strategos of Themistes and Polemon divisions of Arsinoite nome, from Panephremmis, son of Heron, grandson of Heron, his mother Tapheus, both from the village Theadelphia. I register myself for the house-by-house registration of the past $23^{\text {rd }}$ year of the god Aelius Antoninus. And I am the aforementioned Panephremmis, 59 years old, have my residence in a tenement-house of an estate in the village Apias of the same division, therefore I present the declaration. The first year of the Imperator Caesar Marcus Aurelius Antoninus Augustus and the Imperator Caesar Lucius Aurelius Verus Augustus, the first (?) of Mesore.

\section{Commentary:}

$10(\varepsilon \tau \omega \nu)[v] \theta$ : the age of Panephremmis in the lacuna is completed from the other copy (P. Berl. Leihg. 16 B, line 10). Boys became liable to the payment of the

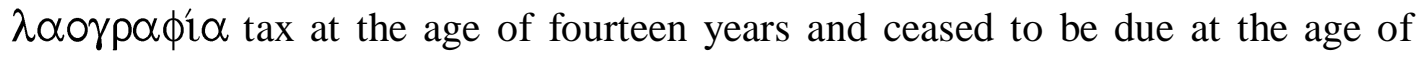
sixty-two years old, see Wallace, Taxation pp.105ff.; Bagnall-Frier, Demography pp.27f.

11 ovvolkí (= Latin: insula) is a house in which several families live in community. The synoikia is normally divided into chambers or flats opposite to olki $\alpha$ (= Latin: domus) a house occupied by one family, see Fritz Luckhard, Das Privathaus im ptolemaeschen und roemischen Aegypten, Giessen 1914, pp. $23 \mathrm{f}$.

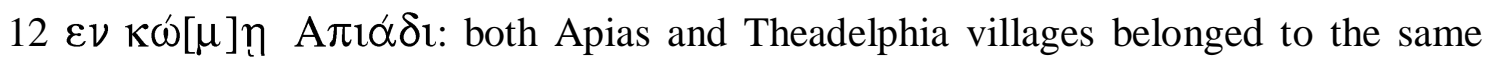
division of Themistes. A more precise location of Apias within the division can only be approximative. According to P.Lond. III 842 (A D 140) the land of Apias was 
south of Herakleia and close to the pedion of Psarbatalis and Pyrros, which belonged to the territory of Philopator Apiados, a neighbouring village of Apias. Stud. Pal. XX 50 (A D 204) suggests that Herakleia and Apias were also next to each other. Hobson puts Apias very much to the south, almost at the border with Polemon division, see Hobson Deborah W. (Samuel): The Village of Apias in the Arsinoite Nome, Aegyptus 62 (1982) pp.80-123. B.Van Beek suggests that this village was close to the lake Moeris and not too far from Euhemeria, see www.trismegistos.org/fayum

$18 \mathrm{M \varepsilon} \sigma[0] \rho[\eta े \alpha]$ : the day is completed in the lacuna from the other copy (P. Berl. Leihg. $16 \mathrm{~B}$, line 19). If the reading is correct, this document will be the earliest for the strategos Harpocration (25 July 161). The latest document for this strategos is P. Berl. Leihg. I 2R (March-May 163), cf. G. Bastianini, Gli Strateghi dell'Arsinoites in Epoca Romana, Pap. Brux.11, Brussel (1972), p. 54.

\section{Sayed Mohamed Omar Gmail: omarsayedm@ hotmail.com}

$$
\text { مويايل: צس ع . 1 1. . 1. }
$$




\section{Two Documents from Cairo Museum}

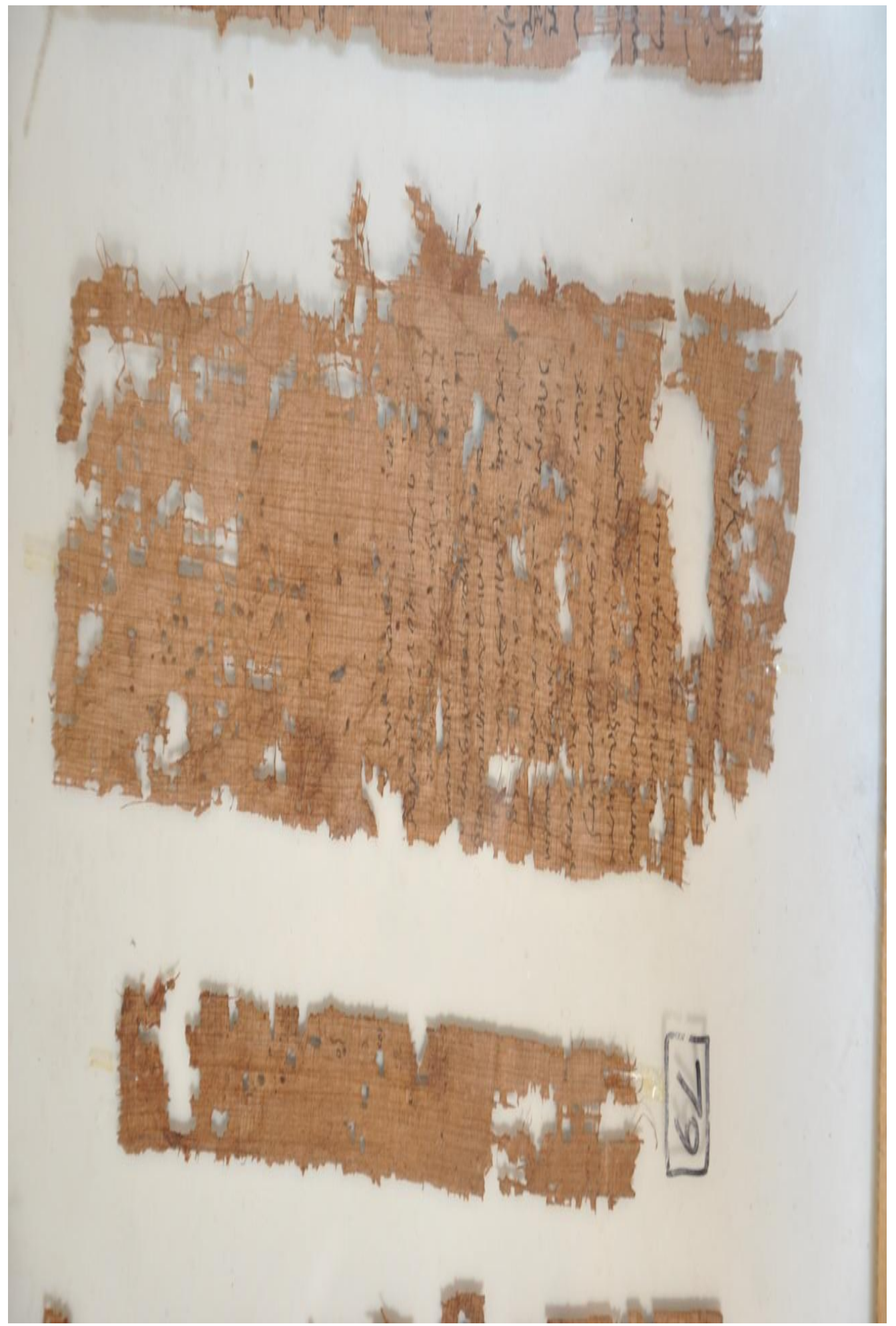

